\title{
COMMENT
}

\section{Every dog has his day in court}

\author{
Gregory A Petsko*
}

The time is the present day. The setting is a Small Claims Court (VERY Small Claims) in some nameless American city. The courtroom is packed. To the right as one faces the judge's bench is a low table at which are seated the plaintiff, an obese tabby cat named Garfinkle, and his attorney, the famous courtroom lawyer Mason Dixon. To the left is another table at which are seated the defendant, a small, wheat-colored mixed poodle/spaniel dog named Clifford, and his attorney, a large chocolate Labrador retriever named Mink. The bailiff enters.

Bailiff: Oyez, Oyez! All rise! This court for the adjudication of small claims is now in session, the Honorable Judge Gregory Petsko presiding. Anyone having any business before this court, draw near and ye shall be heard. God save the United States of America and this court.

Judge Petsko: Be seated. Case before the court is a continuance of the suit brought by the makers of Whiskers Cat Food against the makers of Kibbles and Bits. (Turns to the plaintiff's table) Counselor, when we recessed yesterday you had just completed examining your sixth witness. Do you have any additional witnesses to call at this time?

Mason Dixon (rising): No, Your Honor. The plaintiffs rest. (Sits down.)

Judge Petsko (turning to the defendant's table): Does Council for the Defense wish to make an opening statement at this time?

Mink (rising): Yes, Your Honor. (Mink walks slowly over to the jury box, which is filled with a motley assortment of animals) Ladies and Gen - er, I mean, Fellow Animals of the Jury, it is the contention of Counsel for the Plaintiff

*Correspondence: petsko@brandeis.edu

Rosenstiel Basic Medical Sciences Research Center, Brandeis University, Waltham, MA 02454-9110, USA that the actions of the defendants have caused irreparable harm to his client, the Whiskers Cat Food Company. The gist of their argument, as you have heard during the past few days of testimony, is that the manufacturing and selling of dog food has reduced the shelf space in grocery stores that would otherwise be available for the sale of cat food, thereby causing them to lose a fortune in would-be sales. Rather than attempt to refute their argument point by point, I am now going to ask the judge to rule on the case without my making an argument. This is called Summary Judgment. (Turns to bench) Your Honor, the Defense makes a motion for Summary Judgment in favor of the defendants.

Judge Petsko: This is somewhat irregular (not that I'm surprised at that in this court). Counselor, what are the grounds for your motion?

Mink: Your Honor, the grounds are that the plaintiffs have no standing in this case.

Mason Dixon: Objection! The irreparable harm suffered by the plaintiffs grants standing.

Mink: Your Honor, the idea of irreparable harm in this case is ridiculous. Counsel is arguing that purely hypothetical sales, for which there is no evidence whatsoever, are being lost because dog food is occupying shelf space instead of additional cans of cat food. Disgusting, fish-smelling, pre-digested barf-looking cat food that no one in their right mind would -

\section{Mason Dixon: Objection! Irrelevant!}

Clifford (looking around curiously): An elephant? Where? I don't see -

Mason Dixon (quickly): It doesn't matter what Counsel thinks of cat food. Counsel is, well, being a dog.

Judge Petsko (looking carefully at Mink): Sustained. Counsel will refrain from barking up the wrong tree. (Sits back looking pleased with himself. The entire courtroom groans.) 
Mink: As Your Honor is aware, 'standing' is a legal term that refers to the legal right to initiate a lawsuit. To do so, a person must be sufficiently affected by the matter at hand, and there must be a case or controversy that can be resolved by legal action. Specifically, there must be injury in fact, which means an invasion of a legally protected interest that is concrete and actual or imminent, not conjectural or hypothetical. Further, there must be a causal relationship between the injury and the challenged conduct, which means that the injury fairly can be traced to the challenged action of the defendant, and has not resulted from the independent action of some third party not before the court. Additionally, the prospect of obtaining relief from the injury as a result of a favorable ruling must not be too speculative. It is my client's contention (Turns to the defense table. Clifford has his head down and is taking a nap) - or at least, it would be if he were awake - that the plaintiffs have not shown an injury in fact.

Mason Dixon (rising): Your Honor, it is no longer necessary to show an injury in fact. Anyone can bring suit merely by alleging hypothetical harm.

Judge Petsko: Do you have any authorities to support that statement?

Mason Dixon: Yes, Your Honor. The famous stem cell case, number 10-5287, that was heard in the United States Court of Appeals for the District of Columbia Circuit in the fall of 2010. That's the case of Dr James L Sherley et al. vs Kathleen Sibelius et al. Your Honor will recall that the plaintiffs in that case, Dr James Sherley of the Boston Biomedical Research Institute and Dr Theresa Deisher of Washington-based AVM Biotechnology, who both work with adult stem cells, filed the suit, which sought to block all federal funding for embryonic stem cell research. Congressional authorization for funding of the National Institutes of Health every year for a decade has included the socalled Dickey-Wicker amendment, which specifies that federal funds could not be used for 'research in which a human embryo or embryos are destroyed, discarded, or knowingly subjected to risk of injury or death.' In March of 2009, President Obama had issued an executive order that overturned the policy announced in August 2001 by then-President George W Bush policy that led to the Dickey-Wicker amendment - that barred the use of federal money for any projects using embryonic stem cells created after that date, but allowed work to continue with cells derived from a limited number of stem cell lines already existing. (The idea was that the life-or-death decision had already been made for those embryos.) The Obama policy was intended to permit federal support for studies involving new lines of cells derived from embryos created by in vitro fertilization and donated by couples who no longer wanted them. That policy, which was then turned into new guidelines issued by the National Institutes of Health for researchers, was intended to avoid any conflict with the Dickey-Wicker restrictions by stipulating that the actual extraction of stem cells from embryos would have to have occurred without federal money. But, as Your Honor may remember, Drs Sherley and Deisher, who, remember, did research on adult stem cells, argued that any federally funded embryonic stem cell research violated the DickeyWicker amendment, because embryos had to have been destroyed to make the cells, and the plain intent of the amendment was to prevent such destruction, regardless of when or where the cells were made. They lost their case initially, but appealed to the US Court of Appeals, and at the end of August 2010, Judge Royce C Lamberth of the appellate court issued a preliminary injunction prohibiting all federally funded embryonic stem cell research, regardless of when the embryos were obtained. That decision effectively shut down all such research that wasn't being carried out with foundation or corporate support.

Judge Petsko: I remember the case, but how does -

Mason Dixon: If Your Honor please, I will explain. Judge Lamberth didn't just grant the injunction, he ruled that the plaintiffs had standing in the case.

Mink: Your Honor, that ruling was a disgrace! The plaintiffs proclaimed that they brought the suit because they had ethical objections to destroying human embryos for medical research. They said embryonic stem cell research is morally objectionable and unlikely to produce promised treatments or cures. They said research using adult stem cells, the field each of them works in, has more potential to help patients. But that wasn't the basis for their claim of standing to sue. Their alleged harm wasn't moral; it was purely financial. They claimed that funding embryonic stem cell research would put them at a disadvantage in their effort to get federal research dollars for their adult stem cell research because of competition from embryonic stem cell researchers. That claim is ridiculous. That's now how scientific funding is determined. Every grant application can compete for funding against every other one in a system of peer review, and the best grants get funded. If Dr Sherley didn't get a grant for his adult stem cell project, it was because the project was deemed not to be good enough, not because a bunch of people applied for funding for embryonic stem cell research. Besides, 
in its legal filing in the case, the Obama administration pointed out that Dr Deisher had never even applied for government research funding! So the 'harm' in her case was certainly hypothetical.

Mason Dixon: Nevertheless, Your Honor, the court granted standing. That means that it is no longer necessary to prove actual harm in order to sue to stop something you don't like. All you have to do is show that it might, conceivably, keep you from making money, even if the likelihood of your making that money is extremely remote. And that's exactly the situation here, Your Honor. By preventing cat food from filling up the grocery shelves, dog food manufacturers are robbing my clients of their right to have all animal food profit to themselves.

Mink: But Your Honor, you can see how insidious a ruling like Judge Lamberth's is. Carrying that argument to its logical conclusion, you would only ever fund one research grant: the first one applied for, no matter what the subject was or how good it was. Any subsequent grant application could be blocked from being considered by the people who applied for the first grant because the mere possibility that anything else might be funded would reduce the total amount of money available to fund the first grant, and would also reduce the chances that the first grant would be renewed. Follow that decision where it leads in the case before you here today, and there would be nothing but cat food in every grocery store in the country!

Mason Dixon: Precisely the outcome my client desires, Your Honor.

Judge Petsko (to himself): My mother told me not to go to law school. 'Make something of yourself', she said. 'Become a genome biologist.' But did I listen? No.

Mink: That ruling will destroy the peer review system if it is allowed to stand.

Mason Dixon: Nevertheless, Your Honor, at this moment, that ruling has not been overturned. My clients have standing. We ask that you overrule the motion for Summary Judgment.

Judge Petsko: I'm going to take the motion under advisement at this time, pending further outcome of the embryonic stem cell case. And I'm sure that scientists all over the United States are waiting in trepidation to see how the appeal of the injunction, and the claim of standing, that is being brought by the Obama Administration with the help of most of the major life sciences professional societies, will turn out. (To Mink) Call your first witness.

Mink: The Defense calls Clifford.

Judge Petsko (who knows Clifford): Are you sure you want to do that? I mean, isn't there any other -

Mink: Is Your Honor trying to tell me how to conduct my case?

Judge Petsko (under his breath): Well, somebody should. (Out loud) No, of course not. Clifford to the stand.

Bailiff: Raise your right han - I mean paw. No, the front one! Do you solemnly swear that the testimony you are about to give shall be the truth, the whole truth, and nothing but the truth?

\section{Clifford: Arf!}

Judge Petsko (burying his head in his hands and muttering): Fifty thousand dollars worth of law school debt for this!

Bailiff: State your name.

Clifford (proudly): My name is Get Off The Sofa Clifford.

Judge Petsko (to Mink): I warned you.

Mink (quickly, to Clifford): How much dog food do you eat a day?

Clifford: Not as much as I'd like.

Mink: And if there was nothing but cat food available? If this stupid ruling of the Appellate Court in the embryonic stem cell case is allowed to stand and only cat food can be sold?

Clifford: I'd starve.

Mink (to Mason Dixon): Your witness, Counselor. (Sits down.)

Mason Dixon (to Clifford): Have you ever eaten cat food?

Clifford (nervously): Define 'cat food'.

Mason Dixon: Will the Court please instruct the witness to answer the question.

Mink: Objection! Counsel is badgering the witness. 
Clifford (looking around the courtroom for a badger but not seeing one): Your Honor, I decline to answer on the grounds that it may incinerate me.

Judge Petsko: Incriminate.

Clifford: No, Your Honor. The question is making me burning mad.

Judge Petsko (to Mink): This is your fault.

Mason Dixon (to Clifford): Then you don't even know if cat food tastes good or bad?

Mink: Objection! Counsel is leading the witness. (Clifford checks his collar but finds no leash, so he doesn't see how he can be being led.)

Judge Petsko: Sustained. Rephrase your question, Counselor.

Mason Dixon (thrusts a can of cat food in front of Clifford): Do you know what this is?

Clifford (suddenly): I can't take it any more! I confess! I did it!

Judge Petsko (looking bewildered): Did what? This isn't a criminal cou -

Clifford: I did it! I stole the pork roast off the kitchen counter and ate it! Mink got blamed for it but he was innocent! It was me! I did it!
Mason Dixon (to no one in particular): Another courtroom confession. How do I do it?

Mink (shocked): Your Honor, in view of this startling testimony, I can only say that, if my client is charged with this heinous crime, I'd like to prosecute.

Judge Petsko (sotto voce): I should have listened to my mother.

\section{The defense rests.}

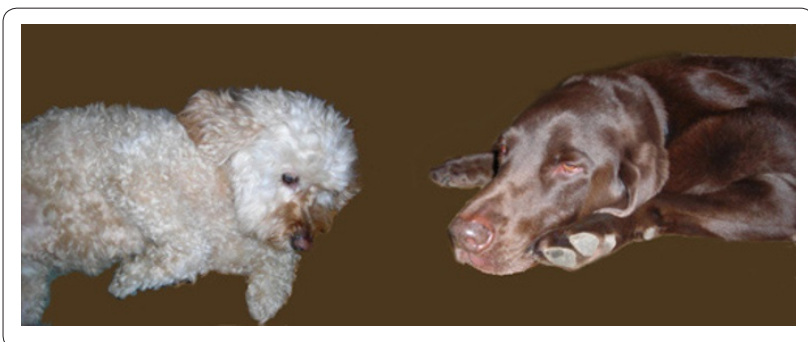

Published: 30 November 2010

doi:10.1186/gb-2010-11-11-139

Cite this article as: Petsko GA: Every dog has his day in court. Genome Biology 2010, 11:139. 